\title{
BUSINESS ETHICS FOR BUSINESS SUSTAINABILITY IN MUHAMMADIYAH HOSPITAL: EVIDENCE FROM PONOROGO, INDONESIA
}

\author{
Anna Marina \\ Faculty of Economics and Business, Universitas Muhammadiyah Surabaya, Indonesia \\ (anna.marina@fe.um-surabaya.ac.id) \\ Sentot Imam Wahjono \\ Faculty of Economics and Business, Universitas Muhammadiyah Surabaya, Indonesia \\ (sentot.imamw@fe.um-surabaya.ac.id)
}

\begin{abstract}
The purpose of this study is to examine how business ethics can support business sustainability in hospitals. Business ethics is associated with: Hospital professional ethics, medical professional ethics, professional accounting ethics, and Islamic business ethics. This study used a qualitative approach with phenomenological analysis techniques to process the data collected from key informants, through Focus Group Discussions (FGD) with 20 supervisors, in-depth interviews with six members of the management, 11 outside observations, and documentation over a period of six months. The business ethics theory was used to guide the research's findings. The business sustainability theory was used to find the relationship of the research's findings with the opinions of four expert informants for the purpose of triangulation on the reasons for conducting Islamic business ethics for a sustainable business. The finding of this study is the reason for running the hospital ethically. The finding of this study can be used to redesign the vision and mission of the hospital as a basis for achieving better performance. The implication of the finding of this research is the need for business ethics in the design of internal systems.
\end{abstract}

Keywords: Islamic business ethics, Muhammadiyah hospital, professional ethics, business sustainability.

\section{INTRODUCTION}

Discussions of sustainable business practices need to be set within a framework of business ethics. Business ethics provides a potential analytical framework through which management practices in general, and sustainability in particular, are evaluated (Lashley, 2016). In the insurance industry, the bankruptcy of the American International Group (AIG) in 2008 was caused by the unethical behavior of its leader in running the business (Ferrell, Friedrich \& Ferrell, 2013). Fisher and Lovell (2012) promoted 'green' practices as business ethics with sustainable businesses for the hospitality and restaurant industry.

In his classic 1973 article, Davis (1973: 321) outlines "the case for and against the business assumption of social responsibilities". Arguing that changing social values impose new demands on economic organizations, Businesses' engagement in social initiatives will become imperative for preserving social support in a "mature, global civilization" (Bronn \& Cohen, 2009). The argument was based on the desire of the business community to be able to produce goods and services to make a profit in the longterm by strengthening the firms' public images (Davies, 2003).

Business continuity in a hospital is primarily affected by the implementation of ethics in the hospital's daily operations. Furthermore, Graaf and Ven (2006) state that corporate social initiatives, as the basis of corporate long-run goals, are genuinely guided by moral values or ethics. A hospital is an integral part of the healthcare system. In the past 25 years, hospitals 
have grown rapidly, both at the provincial and city-district level (Bellman, 2012).

Business continuity is determined by organizational performance, while organizational performance is influenced by organizational culture (Shahzad et al., 2012). Hospital is also an independent business organization where its business continuity is determined by its organizational culture (WHO, 2005). The corporate culture that is applied in the day-today operations of an organization is a reflection of the ethics practiced (Colquitt et al., 2013).

In order to survive and thrive, a hospital is required to maintain and improve the quality of its service-oriented processes and performance, in accordance with the standards of excellent service that accommodate the wishes of its customers. Hospitals need to develop a new paradigm as a healthcare institution business nuances that "Patients are partners in the hospital". This paradigm would leave behind the old paradigm of "Doctor is a king in the hospital". The hospitals' paradigm shift requires hospitals to turn themselves into enterprises that have many strategic profit-oriented business units, while still maintaining the social function as a core product that must be executable (Marina \&Wahjono,2013).

Business has an ethical duty to "give back" to society (Kotler \& Lee, 2005), because this ethical duty could improve the profitability, enhance the reputation, and strengthen employee commitment to the firm, and also expresses an equally strong desire to "make the world a better place "(Graff \& Ven, 2006). Anupam et al. (2011) states that there is an optimistic relationship between business ethics and business success. Therefore, this research seeks to find evidence of a positive relationship between business ethics and the business sustainability of a hospital.

\section{LITERATURE REVIEW}

\section{Business Ethics}

The word ethics in Latin is ethica. Ethos in Greek means the norms, values, rules, measures for right or wrong behavior, good or bad, worthy or inappropriate. In general it can be said that ethics is a moral foundation that includes knowledge of goodness, righteousness and propriety. Or, in other words, ethics provides guidance about the behavior, attitudes, and actions that are recognized, in connection with a particular type of human activity (Wahjono, 2009). Ethics becomes important when there is a difference value about good-bad governance. Trevino and Nelson (2011) stated that ethics has to do with what my feelings tell me is right or wrong. Also, ethics has to do with my religious beliefs; so, being ethical is doing what the law requires, so that is why ethics consists of the standards of behavior our society accepts. Fisher and Lovell (2012) define ethics in two dimensions, which are the morality of consideration and the "right and wrong" dimensions. In this paper, business ethics are articulated as an indication of humans' behavior, attitudes, and activities that rely on morals or religion to guide them to act properly and to avoid any wrong actions.

In Islam there are 6 basic ethics which relate to doing business (Ahmad, 2001). The six business ethics are: 1) Work, 2) honesty, 3) freedom in economic enterprises, 4) justice and protection, 5) generosity, 6) trade but not usury. Meanwhile, Qaradawi (2017) argues that ethics in business and trade in Islam are very important for avoiding unnecessary disputes. It suggests that there are four basic human activities when performing economic activities, namely: Production, consumption, finance, and distribution. Each of these economic activities should be guided by a value system so that they collectively can lead to feelings of calmness and serenity. Thus, Islamic business ethics are the ones that follow Islamic principles and teaching. See the details in Table 1.

In this study, business ethics is defined as a mixed term, drawn from hospitals' professional ethics (based on the Law of the Republic of Indonesia no. 44, 2009), medical professional ethics (IDI, 2012), accounting professional ethics (IAI, 1998), and Islamic business ethics. 
Table 1. Qaradawi Business Ethics

\begin{tabular}{|c|c|}
\hline Activity & Ethics \\
\hline Production & $\begin{array}{l}\text { Work is the main thing in production } \\
\text { Production in halal environment } \\
\text { Protection of natural wealth } \\
\text { Realizing self-reliance } \\
\text { Realizing self-sufficiency }\end{array}$ \\
\hline Consumption & $\begin{array}{l}\text { Spend the treasure in goodness and away from the mind } \\
\text { Not redundant } \\
\text { Be simple }\end{array}$ \\
\hline Financial & $\begin{array}{l}\text { Personal rights recognition } \\
\text { Inheritance recognition } \\
\text { People needs Qur'an and life balance } \\
\text { Rizki and working balance } \\
\text { Eligible workers }\end{array}$ \\
\hline Distribution & $\begin{array}{l}\text { Prohibition of trading goods that are haram } \\
\text { Right, keeping the mandate and being honest } \\
\text { Being fair and away from riba } \\
\text { Compassion and anti-monopoly } \\
\text { Tolerance, brotherhood, and alms }\end{array}$ \\
\hline
\end{tabular}

Source: Qaradawi, 2017.

Hospitals' professional ethics refers to the obligations and rights of a hospital, as specified in the Law of the Republic of Indonesia Number 44 of 2009 on hospitals, in particular Articles 29 and 30, so hospitals' professional ethics are all matters related to the rights and obligations of a hospital in serving its patients, including the fulfillment of those rights and obligations based on moral and religious principles. The ethics of the medical profession refers to the decree of the IDI (2012). This decree explains that the code of ethics (KODEKI) is a guideline for Indonesian physicians to carry out the practice of medicine. Indonesia's code of medical ethics was first conceived in 1969 by the Indonesian medical working group. They used, as reference material at that time, the international code of ethics that had been enhanced in 1968 to list 22 items by the World Medical Association Congress, which was then refined again at the National Conference XIII of the IDI, in 1983. The profession of doctor is a noble profession, as shown by its six basic properties, namely: 1 ) The nature of divinity, 2) the purity of intention, 3) magnanimity, 4) humility, 5) seriousness of work and 6) scientific and social integrity. These six properties are embodied in KODEKI. The code of ethics for doctors includes general liability, the liability of doctors to patients, a doctor's obligation to his/her peers, and the obligations of a doctor toward him/herself. So the ethics of the medical professions are the rules governing the doctor and patient relationship professionally, including the seriousness of the work.

The ethics of the accounting profession in Indonesia are stipulated by the code of accountants (IAI, 1998), intended as the guidelines and rules on fulfilling their professional responsibilities for all the members, whether they practice as a public accountant, work in the corporate world, or in government agencies, as well as in educational environments. The Indonesian Institute of Accountants' code of ethics consists of eight parts, namely: Responsibility of professionals, public interest, integrity, objectivity, competence and professional prudence, confidentiality, professional behavior, and technical standards. So the ethics of the accounting profession in Indonesia is the norm that governs the accountant professionally, including when determining medical and nonmedical charges in a hospital. 


\section{Business Sustainability}

In term of sustainable development, ethics support the economy (Payne \& Raiborn, 2001). At the business level, sustainability can be split into three types: Economic, natural, and social capital. From this basis, six criteria will have to be satisfied: Eco-efficiency, socio-efficiency, eco-effectiveness, socio-effectiveness, sufficiency, and ecological equity (Dyllick \& Hockerts, 2002). By definition, eco-efficiency is an effort to achieve business sustainability by using and managing the disposal of scarce resources, so as to maintain an ecological environment. The definition of socio-efficiency is the optimal distribution of resources in the community, taking into account all the external costs and benefits, as well as the internal cost and benefits. Eco-effectiveness is the effort to achieve ecological effectiveness through system-transforming, socially committed environmental businesses characterized by breakthrough innovations. Socio-effectiveness is corporate social responsibility; it means continuing the businesses' commitments to behaving ethically and contributing to the economic development, while enhancing the quality of life of the workforce and family within the community and society. Sufficiency is the condition or quality of being adequate. Ecological equity is a system approach with a global perspective on the use of human resources, economic development and the environment as an equity owned by a company.

When transposing this idea to the business level, corporate sustainability can accordingly be defined as meeting the needs of a firm's direct and indirect stakeholders (such as shareholders, employees, clients, pressure groups, communities, etc.), without compromising its ability to meet the needs of future stakeholders as well (Gladwin at al., 1995a). Toward this objective, firms have to maintain and grow their economic, social, and environmental capital bases while actively contributing to sustainability in the political domain. From this definition, three key elements of corporate sustainability can be identified: Integrating the economic, ecological, and social aspects of a 'triple-bottom-line' (Gladwin et al., 1995b).
Within the framework of enterprise strategy, a value system based on sustainability can provide a sound ethical basis for developing an ecologically sensitive strategic management system that allows an organization to satisfy the demands of the myriad green stakeholders that represent the planet in the immediate business area (Wahjono, 2010). Bronn and Cohen (2009) found three key questions when they presented the result of their exploratory research, conducted with managers from over 500 Norwegian companies, which examined corporate motives for engaging in social initiatives. First, what do managers in the sample see as the primary reasons for their company to engage in activities that benefit society? Second, do the motives for such a social initiative vary across the industries represented? Third, can further empirical support be provided for the theoretical classification of social initiative motives outlined in the literature?

In this paper, business sustainability is defined as business continuity that is sustained by eco-efficiency, socio-efficiency, eco-effectiveness, socio-effectiveness, sufficiency, and ecological equity in the long-term.

In this paper we mix some professional ethics to see how they relate to business sustainability, because business ethics is the norm of propriety and wrong and right, and good and bad, so the business ethics in the hospital are a mixture of the ethics of all the professions involved in a hospitals operation, which in this case are the medical staff and other non-medical professions. This paper also involves Islamic business ethics because the research is done in an Islamic hospital.

\section{Hospital Management}

The hospital is an institution for health care professionals; its services are provided by doctors, nurses, and other health professionals. The term hospital is derived from the Latin word meaning host (or the host), which is also the root of the word hotel and hospitality. Some patients may only come for minor diagnosis or treatment; others can be hospitalized for days, weeks, or even months. A hospital is distinguished from 
other health institutions by its ability to provide diagnostic and medical treatment to the patient as a whole. The definition of a hospital, according to the WHO (2005), and the WHO's Expert Committee on the Organization of Medical Care, which is an integral part of any social and medical organization, is to provide for the population complete health care, both curative and preventive and which covers patient service to the family and the home environment, and also to be a center for the training of health workers and for biosocial research. So the health services provided by a hospital can be curative (treatment) or preventive (prevention).

The recent problems faced by hospital managers not only highlight the complaints of people who feel disappointed with hospitals' services, because of their quality, lack of ease accessing them, and rate, but also the modern developments and the paradigm shift of the hospitals' philosophy (Widodo, 2009). There are several reasons to improve a hospital's management, namely: 1) The rapid developments in science and medical technology, and 2) the increased and widespread demands of society (Bellman, 2012).

Based on the findings of Bronn and Cohen (2009) and Graafland and Van de Ven (2016) we want to examine the relationship between business ethics and business sustainability in a hospital, which can then be synchronized with the findings of Marina and Wahjono (2013) by incorporating elements of the hospital's professional ethics, medical professional ethics, accounting professional ethics and Islamic business ethics as the shaper of the hospital's vision and mission.

Table 2 Resume of Previous Research

\begin{tabular}{|c|c|c|c|}
\hline Title & $\begin{array}{l}\text { Research } \\
\text { Objectives }\end{array}$ & Result & Conclusion \\
\hline $\begin{array}{l}\text { Corporate Motives for Social } \\
\text { Initiative: Legitimacy, } \\
\text { Sustainability, or the Bottom } \\
\text { Line? Bronn, Peggy Simsic, } \\
\text { and Cohen, Deborah Vidaver. } \\
\text { 2009. Journal of Business } \\
\text { Ethics. }\end{array}$ & $\begin{array}{l}\text { To investigate the } \\
\text { motives for social } \\
\text { initiatives }\end{array}$ & $\begin{array}{l}\text { Reasons for corporate social } \\
\text { engagement: } \\
\text { 1. Improve image, } \\
\text { 2. Be recognized for moral } \\
\text { leadership, } \\
\text { 3. Serve long-term company } \\
\text { interests. }\end{array}$ & $\begin{array}{l}\text { Motivating factor for the } \\
\text { social initiative: } \\
\text {. Business sustainability } \\
\text {. Legitimacy for business } \\
\text { ethics } \\
\text {. Profitability }\end{array}$ \\
\hline $\begin{array}{l}\text { 'Strategic and Moral } \\
\text { Motivation for Corporate } \\
\text { Social Responsibilities'. } \\
\text { Graafland, J. And B. Van de } \\
\text { Ven. 2016. Journal of } \\
\text { Corporate Citizenship. }\end{array}$ & $\begin{array}{l}\text { To examines the } \\
\text { relationship } \\
\text { between CSR with } \\
\text { business } \\
\text { sustainability and } \\
\text { moral (ethical) } \\
\text { motives. }\end{array}$ & $\begin{array}{l}\text { 1. CSR has a positive } \\
\text { influence on financial } \\
\text { results in the long term } \\
\text { (sustainability). } \\
\text { 2. To behave in a } \\
\text { responsible way is a } \\
\text { moral (ethical) duty of } \\
\text { businesses towards } \\
\text { society. }\end{array}$ & $\begin{array}{l}\text { There is a positive } \\
\text { relationship between CSR } \\
\text { with sustainability and } \\
\text { business ethics. }\end{array}$ \\
\hline $\begin{array}{l}\text { Business Ethics as a Basis } \\
\text { For Designing the Vision } \\
\text { And Mission of Hospitals: } \\
\text { Empirical Evidence From } \\
\text { Muhammadiyah Hospital } \\
\text { Ponorogo, Indonesia. } \\
\text { Marina, Anna and Wahjono, } \\
\text { Sentot Imam. 2013. Journal } \\
\text { of Economics, Business and } \\
\text { Accounting - Ventura. }\end{array}$ & $\begin{array}{l}\text { To identify } \\
\text { business ethics } \\
\text { practiced in } \\
\text { hospital-based } \\
\text { religious values as } \\
\text { the basis for } \\
\text { designing the } \\
\text { vision and mission. }\end{array}$ & $\begin{array}{l}\text { The business ethics divided } \\
\text { into } 3 \text { major groups: } \\
\text { 1. Ta'awun (mutual help) } \\
\text { 2. Tawashi (reminding each } \\
\text { other). } \\
\text { 3. Fastabikhul Khoirot } \\
\text { (competing in goodness). }\end{array}$ & $\begin{array}{l}\text { Could be the vision of } \\
\text { Muhammadiyah Hospital, } \\
\text { more or less is: "Being a } \\
\text { leading Islamic Hospital, } \\
\text { which is reliable and } \\
\text { becoming a reference for } \\
\text { public health care in the } \\
\text { world and the hereafter". }\end{array}$ \\
\hline
\end{tabular}

Source: Source: Bronn et al (2009), Graafland \& Van de Ven (2016), Marina \& Wahjono (2013) 


\section{Research Framework}

The framework of the study, in accordance with the background and literature review above, is as shown in Figure 1 below:

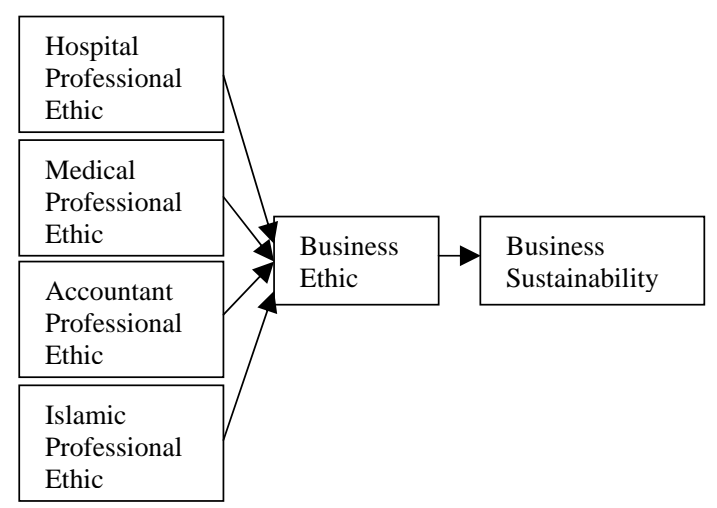

Figure 1 Theoretical Framework

The theoretical framework, as shown in Figure 1, is built from the logical framework that is constructed from the business ethics in the hospital, which are shaped by the ethics that develop in hospitals, such as hospital professional ethics, medial professional ethics, accounting professional ethics and Islamic business ethics. Then, business ethics will affect the business's sustainability in the long run.

\section{METHODS}

This study used a qualitative approach, with the purpose of uncovering the broader perspective on the implementation of business ethics at the hospital. Additionally, this approach was adopted because of the reality that humans are social and spiritual beings; in their daily activities human beings cannot be treated mechanistically. Researching on human beings with all their behavior is included in the decision-making process. That human's behavior always seeks to achieve the purpose of life implies the research in a complex process. In addition, the study will involve various disciplines (economics, management, organizational behavior, psychology, sociology, and accounting) and will direct researchers to improve the perspectives and handle the complex issues and problems (Creswell \& Clark, 2007).
This qualitative study using a phenomenological approach aims to uncover and understand the meaning behind the phenomenon of the actions of individuals who perform various acts on the basis of their own perception, as well as various aspects of the underlying actions. The research was conducted with data collected from Focus Group Discussions (FGD), in-depth interviews and outside observations. For the indepth interviews, a series of questions were prepared with the aim of answering the research question. The questions posed were not structured but flowed with the rhythm of the FGD and the in-depth interviews, with a view to eliminating the rigid and drab atmosphere. Meanwhile, the external observations were conducted to obtain an objective perspective on some of the findings found either through the interviews or through secondary data. Observations from the outside are also useful to obtain a starting point when designing research questions.

FGD was held on December 1, 2014, and involved 20 employees (21 were invited, one was absent due to illness) in the chamber of the hospital RSUAP (Rumah Sakit Umum Aisiyah Ponorogo) health committee. The FGD was attended by the director of the RSUAP and all its leaders including two deputy directors and three heads of sections. The FGD was opened by the managing director with a speech about the importance of the FGD and the guarantee of freedom of speech during it. The FGD went well, and was warm and open. Beginning at 9 am and ended at $5 \mathrm{pm}$ with a one hour break for meals and Dhuhr prayers, the FGD was held in a circle, with the 20 participants seated at a table, while on the left of the circle the moderator (an expert on FGD) and the principal investigator sat. On the far right of the circle two documenters sat. One of the documenters was free to move about the room to record the course of the FGD.

In-depth interviews were conducted during a period of three months involving a director, two deputy directors and three heads of sections. The interviews were conducted in a flexible manner. They were sometimes held in an office, while 
the interviewees were reviewing the condition of the hospital, or when they were in charge the next day. Interviews were also conducted outside of working hours and outside the hospital.

Observations from the outside were held during a period of three months from October 7 until December 20, 2014. These observations put the researcher as an outsider who had no connection with RSUAP. Observations were made with the patients and their families, without the knowledge of the hospital's employees and management. Observations were conducted in order to confirm the above findings from the FGD and the answers from the interviews. During this observation period interviews were also conducted with 10 patients and their families.

Triangulation was held to test the validity of the answers from the FGD and the in-depth interviews. Triangulation was also carried out to test the reliability of the nine topics discussed during the focus group discussions and in-depth interviews. Triangulation was done by asking the opinion of four experts on studies conducted by Muhammadiyah and experts on social, environmental and especially ASEAN and Indonesian studies. The experts included the chairman who is in charge of social welfare at the hospital, the Chairman of the Institution Regional Leadership of East Java, the Chairman of the Advisory Board of the National Agency for Disaster Management, and a MARS (Magister Rumah Sakit) assessors of national hospitals, who is a former director of a private hospital. The interviews with the experts (expert informant) were conducted during the three months of the study period.

\section{RESULTS AND DISCUSSION}

The following data were derived from the results of the focus group discussions with the informants, held 11 times over a six month period. We held interviews with six members of RSUAP's management on 10 occasions, at several locations inside and outside of RSUAP, and also with the four expert informants.

\section{Business Ethics Practiced}

In a previous study, Marina \& Wahjono (2013) found RSUAP's institutional values, as follows:

1. Provide goods and services in high quality,

2. Improve knowledge and skills,

3. Achieve objectives within the budget,

4. Able to develop oneself,

5. Establish good relations,

6. Thriftiness,

7. Communicate politely and truthfully,

8. Not distinguishing between patients,

9. Help poor patients,

10. Maintain and strengthen the faith of patients,

11. Discipline,

12. Empathy,

13. Work sincerely,

14. Working faster, more accurately and more carefully,

15. Initiative,

16. Sincerity.

The values are separated into 3 major groups of business ethics (Marina et al., 2014), namely:

1. Ta'awun (mutual help), meaningful help for each other in order to realize the concept of goodness Rahmatanlil Alamin (blessings for the entire universe).

2. Tawashi (reminding each other), meaningful advice for each other in goodness and to avoid evil and uphold the noble behavior (akhlakul kharimah).

3. Fastabikhul Khoirot (competing in goodness), means competing to in favor by working with the best possible intentions as a form of worship and carrying out the mandate.

There are 10 topics in the focus group discussion, submitted by the moderator one at a time and answered by the participants. Sometimes the participants' answers did not follow the order of the topic's focus. This was not an issue and indeed such conditions were desirable so that the atmosphere became warm, not rigid, because there was a possibility that the opinion of a participant may not be the same as the opinion of the other participants, allowing for mutual criticism among the participants. 
The 10 focused topics consisted of four subjects connected with business ethics and six topics to do with business sustainibility. The four business ethics topics included hospital professional ethics, medical professional ethics, business accounting ethics and Islamic business ethics. The six topics on business sustainability included eco-efficiency, socio-efficiency, ecoeffectiveness, socio-effectiveness, sufficiency, and ecological equity. Some questionnaires were designed to reflect the six criteria for a business's sustainability in the preceding literature review by connecting business ethics with business sustainability (see Table 3).

\section{Reasons to Run the Business Ethically}

A total of six managers responded that the reason for applying business ethics was to allow for social effectiveness, while one person in management responded that it was for reasons of sufficiency. The many answers come to socioeffectiveness with a total of 12 if only 8 supervisors answer for reasons of sufficiency.

One manager, two supervisors and one expert informant answered that socio-efficiency is the benefits of having a business ethic with the intent of social sustainability. On the other side, three managers, two supervisors and one expert informant answered that socio-effectiveness's criteria required it. Next, one manager, 11 supervisors, and one expert informant answered for the sufficiency criteria. Besides, one manager, five supervisors, and one expert informant answered the ecological equity.

Table 3. English translation of Indonesian guidance questions and criteria labels

\begin{tabular}{|c|c|c|}
\hline No. & Guidance Question & Criteria \\
\hline 1 & $\begin{array}{l}\text { We can engage in social activities to serve our hospital's long-term interests } \\
\text { with our business ethics }\end{array}$ & Socio-efficiency \\
\hline 2 & $\begin{array}{l}\text { Engaging in social activities can improve our image and represent our } \\
\text { business ethics }\end{array}$ & Socio-effectiveness \\
\hline 3 & $\begin{array}{l}\text { Refering to our business ethics, we must engage in social activities to } \\
\text { maintain our position against our competitors }\end{array}$ & Sufficiency \\
\hline 4 & If we do not engage in social activities, the regulator will force us to do so & Ecological equity \\
\hline 5 & $\begin{array}{l}\text { People inside and outside our hospital expect us to engage in social activities } \\
\text { to reflect our business ethics }\end{array}$ & Sufficiency \\
\hline 6 & $\begin{array}{l}\text { To implement our business ethics, our shareholders demand that we engage in } \\
\text { social activities }\end{array}$ & Sufficiency \\
\hline 7 & $\begin{array}{l}\text { As a private firm, we can solve social problems better than a government } \\
\text { agency can because we have business ethics }\end{array}$ & Eco-efficiency \\
\hline 8 & $\begin{array}{l}\text { Since we have business ethics, our hospital has valuable resources that can be } \\
\text { used to solve social problems }\end{array}$ & Socio-efficiency \\
\hline 9 & $\begin{array}{l}\text { Encouraging business ethics, our hospital can earn money by solving social } \\
\text { problems }\end{array}$ & Ecological equity \\
\hline 10 & $\begin{array}{l}\text { If we do not take action to address social problems, they could harm our } \\
\text { primary business }\end{array}$ & Sufficiency \\
\hline 11 & $\begin{array}{l}\text { People in our hospital are concerned with social problems and want to help } \\
\text { because we have business ethics }\end{array}$ & Socio-effectiveness \\
\hline 12 & Our business ethics make us feel good when working on social problems & Sufficiency \\
\hline 13 & There is no good reason not to engage in social activities & Socio-effectiveness \\
\hline 14 & Engaging in social activities can build networks with foreign cultures & Ecological equity \\
\hline 15 & $\begin{array}{l}\text { We wish to be seen at the forefront of society's legal, moral and ethical } \\
\text { standards representing our business ethics }\end{array}$ & Sufficiency \\
\hline 16 & $\begin{array}{l}\text { Our business ethics encourage us to gain knowledge from social service } \\
\text { organizations }\end{array}$ & Socio-effectiveness \\
\hline
\end{tabular}

Source: Modified from Bronn and Cohen (2009) 
Table 4. Matrix for informant's answers by criteria

\begin{tabular}{|c|c|c|c|c|c|c|c|c|c|c|c|c|c|c|c|c|c|c|}
\hline \multirow[t]{2}{*}{ No. } & \multirow{2}{*}{$\begin{array}{c}\text { Result } \\
\text { Criteria }\end{array}$} & \multicolumn{6}{|c|}{ Management (6) } & \multicolumn{5}{|c|}{ Supervisor (20) } & \multicolumn{6}{|c|}{ Expert (4) } \\
\hline & & 1 & 2 & 3 & 4 & 5 & 6 & 1 & 2 & 34 & 5 & 6 & 1 & 2 & 3 & 4 & 5 & 6 \\
\hline 1 & $\begin{array}{l}\text { Reasons to } \\
\text { implement business } \\
\text { ethics }\end{array}$ & & & & 5 & 1 & & & & 12 & 8 & & & & & 2 & 2 & \\
\hline 2 & $\begin{array}{l}\text { Advantage when } \\
\text { implementing } \\
\text { business ethics }\end{array}$ & & 1 & & 3 & 1 & 1 & & 2 & 11 & 2 & 5 & & & 2 & 2 & & \\
\hline 3 & $\begin{array}{l}\text { Threat if they do } \\
\text { not implement } \\
\text { business ethics }\end{array}$ & & & & & 4 & 2 & & & & 17 & 3 & & & & & 3 & 1 \\
\hline 4 & $\begin{array}{l}\text { Long-term } \\
\text { interest in } \\
\text { implementing } \\
\text { business ethics }\end{array}$ & 1 & 1 & & & 4 & & 10 & 5 & & 5 & & 1 & 1 & & & 2 & \\
\hline & Sub-Total & 1 & 2 & & 8 & 10 & 3 & 10 & 7 & 14 & 41 & 8 & 1 & 2 & & 3 & 8 & 2 \\
\hline & Total & & & & 4 & & & & & 80 & & & & & 1 & 6 & & \\
\hline \multicolumn{19}{|c|}{ riteria: } \\
\hline & $\begin{array}{l}\text { 1. eco-efficiency, } \\
\text { 3. eco-effectiveness, } \\
\text { 5. sufficiency, }\end{array}$ & & & & & & $\begin{array}{l}\text { ocio } \\
\text { colo }\end{array}$ & $\begin{array}{l}\text {-effic } \\
\text {-effe } \\
\text { gical }\end{array}$ & tive & & & & & & & & & \\
\hline
\end{tabular}

Four managers, 17 supervisors, and three expert informants answered that the criteria of sufficiency is related to the threats if they do not run the business ethically. Then, two managers, three supervisors, and one expert informant answered that the sociological equity criteria was.

As related to the long-term interest in the implementation of business ethics, 10 supervisors, and one expert informant answered that the criteria of eco-efficiency by one manager was more relevant. However, there were one manager, five supervisors, and one expert informant who answered that the socioefficiency criteria was the most related one. Besides, four managers, five supervisors, and two expert informants answered that the sufficiency criteria was more appropriate. The details can be seen in Table 4. As for the threat of what happens if they do not run the business ethically, it was answered by four members of the management, 17 supervisors, and three expert informants, they replied that placing it in the sufficiency criteria was the more relevant answer. Furthermore, two managers, three supervisors, and one expert informant answered that the socio-efficiency criteria prevailed.

\section{DISCUSSION}

For the reason why business ethics should be implemented, most informants answered that the reason is for sufficiency, particularly with the statement: "We wish to be seen at the forefront of society's legal, moral and ethical standards that represent our business ethics, and people inside and outside our hospital expect us to engage in social activities to reflect our business ethics." This is understandable because the people around Ponorogo look to the hospital as a healthcare institution that has the capability to conduct social activities, in terms of the doctors and medical personnel and medical equipment available to help the local communities. This finding is not in line with Bronn and Cohen (2009) and Stead and Stead (2000). This may occur because of differences in the industry 
where the hospital is operating, i,e, the healthcare industry. As described above, the motive for ethical implementation of business sustainability in hospitals is sufficiency and socio-effectiveness as a manifestation of a strong desire to create a better world place for future generations (see Aguilera et al., 2007). As described above, sustainability motives for society's legal, moral and ethical standards, a sense of organizational responsibility, and the belief that a hospital has a moral obligation to invest in making the world a better place for future generation (see Aguilera et al.,2007). As for the advantages of implementing business ethics, most of the informants answered for the socio-effectiveness, particularly with the statement: "Engaging in social activities can improve our image and represent our business ethics." Although the hospital is a business institution, the need for it to have an image as an institution that cares about the interests of society is still strong in the minds of managers and supervisors. This finding is consistent with Bronn and Cohen (2009), and is also in line with Stead and Stead (2000). Other criteria that appear in response to this statement are socioefficiency, ecological equity, and sufficiency. This is understandable because the hospital is also expected to be a business institution that is able to support itself financially, so that it should not be a loss-making enterprise. If it is, in the long run, it will be closed and thus unable to serve the public again. Therefore, hospitals must maintain their equity and socio-ecological efficiency, and should have a positive image attached to them. This finding is also consistent with Bronn and Cohen (2009), Stead and Stead (2000), and Dyllick and Hockerts (2002).

To reply the question of threat if they do not run a business ethics, most of the informants answered for sufficiency, particularly with the statement: "If we do not take action to address social problems, they could harm our primary business." This is understandable because the presence of the hospital in the community is expected to contribute to the improvement of public health conditions. If the hospital does not implement its business ethics to better serve society, then the hospital is not able to continue its business activities. Of course, this will result in the absence of an income for the doctors and medical personnel working in the hospital. This finding is consistent with Bronn and Cohen (2009) and is also in line with Stead and Stead (2000). Another criterion that appeared in response to this statement was ecological equity. This is because hospitals have skilled personnel and adequate equipment to keep their environment clean and comfortable. Therefore, hospitals must maintain ecological equity and should be seen to have a positive image attached to them. This finding is also consistent with Bronn and Cohen (2009), and Stead and Stead (2000).

Concerning the long-term interest question for running on business ethics, most of the informants answered that the sufficiency prevailed. It was particularly inline with the statement: "Refering to our business ethics, we must engage in social activities to maintain our position against our competitors." The reason that surfaced is that business institutions are also required to act commercially. Hospitals have competitors that want to compete and even to beat each other. If the hospital does not implement its business ethics to maintain its sustainability by maintaining its position against its competitors by serving the community better, then the hospital is afraid to be abandoned and this will affect its business in the long term; it will decrease the income and then die. This finding is consistent with Bronn and Cohen (2009) and also in line with Stead and Stead (2000). Besides, socio-efficiency and ecoefficiency were found as the main criteria. This is because the hospital, as a health institution that has operated for a long time, is expected to be able to demonstrate its efficiency in both social and ecological environment. This finding is also consistent with Bronn and Cohen (2009), and Stead and Stead (2000). These findings confirmed that the hospital still has strong profitability motives. This interpretation is consistent with the observations of other informants who feel that even a social activity can serve as a profit guarantor. The success of 
this strategy relies heavily on the relationship between the hospital's social activities and its core business (see Peloza, 2006).

\section{CONCLUSION}

This study managed to find a relationship between four causes of hospitals implementing their business ethics to achieve the six criteria of sustainability. In general, applying business ethics to a hospital ensures the sustainability of the hospital, for its own sake, and the sake of the local community, the government and also the hospital's stakeholders. The limitations outlined above suggest several review directions for future research. First, the guidance questions could be administered to the hospital's experts, especially to access the cultural generalizability of our result. The study could be replicated with quantitative methods to uncover the generalizability's purpose. This might reveal very different outcomes than research reporting the perceptions of the managerial level only.

\section{REFERENCES}

Aguilera, R.V., D.E. Rupp, C.A. Williams. and J. Ganapathi, 2007. "Putting the S Back in Corporate Social Responsibility: A Multilevel Theory of Social Change in Organizations." Academy of Management Review, 32 (3), 836-863.

Ahmad, M., 1999. Business Ethics in Islam. New Delhi: Kitab Bhavan Publisher.

Al Qaradawi, Y., 2017. Ethics of Islam. Arab Network for Research and Publishing. Qatar: Dar Al Mashriq.

Anupam K., G.S. Dangayach, and R. Jain, 2011. "Business Ethics: A Sustainability Approach." Proceeding International Conference on Asia Pacific Business Innovation \& Technology Management. Procedia - Social and Behavioral Sciences, 25, 281-286.

Bellman, E., 2012. "Indonesia Writes Script for Medical Sector." Asian Business News, October 18.

Bronn, P.S. and D.V. Cohen, 2009. "Corporate Motives for Social Initiative: Legitimacy, Sustainability, or the Bottom Line?” Journal of Business Ethics, 87, 91-109.

Carroll, A.B., J. A., Brown, and A.K. Buchholtz, 2015, Business \& Society: Ethics, Sustainability, and Stakeholder Management. Tenth Edition. Cengage Learning. Singapore.

Colquitt, J.A., J.A. Lepine, and M.J. Wesson, 2013. Organizational Behavior, Improving Performance and Commitment in the Workplace. New York: McGraw-Hill Irwin.

Creswell, J.W., and C.V.L. Plano, 2007. Designing and Conducting Mixed Methods Research.California: Sage Publications, Inc.

Davies, R., 2003. The Business Community: Social Responsibility and Corporate Value, in J.H. Dunning (ed.), Making Globalization Good: The Moral Challenges of Global Capitalism (Oxford University Press, New York, NY). 301-309.

Davis, K., 1973. "The Case for and Against Business Assumption of Social Responsibilities." Academy of Management Journal, 16 (2), 312-322.

Dyllick, T., and K. Hockerts, 2002. "Beyond the Business case for Corporate Sustainability." Business Strategy and the Environment, 11, 130-141.

Ferrell, OC., J. Friedrich, and L. Ferrell, 2013. Business Ethics, ethical decision-making and cases. Ninth edition. Mason, USA: South-Western, Cengage Learning.

Fisher, C., and A. Lovell, 2012. Business ethics and values. London: Prentice-Hall.

Gladwin, T., J. Kennelly, and T.S. Krause, 1995a. "Shifting paradigms for sustainable development implications for management theory and research." Academy of Management Review, 20 (4), 874-907.

Gladwin, T., J. Kennelly, and T.S. Krause, 1995b. "Beyond eco-efficiency: towards socially sustainable business." Sustainable Development, 3, 35-43.

Graafland, J., and B. Van de Ven, 2016. "Strategic and Moral Motivation for Corporate Social Responsibilities.” Journal of Corporate Citizenship, 22, 111-123.

IAI (Ikatan Akuntan Indonesia), 1998. Kode Etik Ikatan Akuntan Indonesia. [Code of Ethics of Indonesian Institute of Accountants] Jakarta: IAI.

IDI (Ikatan Dokter Indonesia), 2012. Surat 
Keputusan Pengurus Besar (PB) Ikatan Dokter Indonesia (IDI) nomor 221/PB/A.4/ 04/2012 tanggal 16 Februari 2012 tentang Penerapan Kode Etik Kedokteran Indonesia (KODEKI) [Decree of the Indonesian Medical Association Board No. 221/PB/A.4/ 04/2012 dated 16 February 2012 regarding the Application of Indonesian Medical Ethics]. Jakarta: PengurusBesar IDI.

Kotler, P., and N. Lee, 2005. Corporate Social Responsibility, Doing the Most Good for your Company and your Cause. (Willey, Hoboken, NJ).

Lashley, C, 2016. "Business ethics and sustainability." Research in Hospitality Management, 6 (1), 1-7.

Marina, A., S. Bambang, W. Hari, and J.G. Nirbito, 2014. "Economic Literacy for the Basis of Organizational Performance Improvement: Evidence from Muhammadiyah Hospital Indonesia.” Journal of Asian Scientific Research, 4 (11), 664-676.

Marina, A., and S.I. Wahjono, 2013. "Business Ethics as a Basis for Designing the Vision and Mission Hospitals: Empirical Evidences from Muhammadiyah Hospital Ponorogo, Indonesia.” Journal of Economics, Business and Accounting - Ventura, 16 (3), 399-408.

Marina, A., 2013. "Meningkatkan Kinerja Berbasis Nilai-nilai Ekonomi pada Amal Usaha Muhammadiyah Bidang Kesehatan. [Improving Economic-Value-Based Performance at Healthcare Business of Muhammadiyah]" Jurnal SALAM, 15(2).

Payne, D.M., and C.A. Raiborn, 2001. "Sustainable Development: The Ethics support the Economics." Journal of Business Ethics, 32, 157-168.
Peloza, J., 2006. "Using Corporate Social Responsibility as Insurance for Financial Performance, California Management Review, 48 (2), 52-72.

Shahzad, F., A.L. Rana, R.K. Ayesha, and S. Lalarukh, 2012. "Impact of Organizational Culture on Organizational Performance: An Overview." Interdisciplinary Journal of Contemporary Research in Business, 3 (90), 975-985.

Stead, J.G., and E. Stead, 2000. "Eco-Enterprise Strategy: Standing for Sustainability.” Journal of Business Ethics, 24, 313-329.

Trevino, L.K. and K.A., Nelson, 2011. Managing Business Ethics. 5th Edition. Hoboken, NJ, USA: John Wiley \& Sons, Inc.

Undang-undang Republik Indonesia nomor 44 tahun 2009 tentang Rumah Sakit. [Indonesian Law No. 44 Year 2009 regarding Hospitals].

Wahjono, S.I., 2009. Perilaku Organisasi. [Organisational Behaviors] Yogyakarta: Penerbit Graha Ilmu.

Wahjono, S.I., 2010. Bisnis Modern. [Modern Businesses] Yogyakarta: Penerbit Graha Ilmu.

World Health Organization. 2005. Human Resources and Training in Mental Health.

Mental Health Policy and Service Guidance Package. WHO.

Widodo, J.P. 2009. Pemasaran Rumah Sakit Berbasis Balanced Scorecard. [BalancedScorecard-Based Hospital Marketing]. Makalah Safari Manajemen Persi di Tulungagung, 27 Juli 2009. (Paper presenter at Persi Management Seminar at Tulungagung on 27 July 2009)

Notice: The Journal of Indonesian Economy and Business and its Board of Editors are not responsible for any errors or flaws found in this article. The authors take full responsibility for their work. 